\title{
Greetings from the Last Issue of 2019 and Special Thanks to All Members of CDJ!
}

In 2019, Cumhuriyet Dental Journal underwent a major renewal with its rich content and increasing international colleagues. As a result of the process I managed with the vision that Cumhuriyet Dental Journal should be a more internationally recognized journal, in 2019 we had the opportunity to publish the articles of many authors from different countries. I hope that the number of authors from other countries in Cumhuriyet Dental Journal will increase gradually next year.

Cumhuriyet Dental Journal received 235 submissions in 2019 and reached the highest level in its publication history. However, our acceptance rate is $26 \%$. For this reason, the review process of our journal has become more selective.

The new policy of our journal to be held since 2020, and revised Author Guideline is now published in our website. The authors, who will also submit new papers to Cumhuriyet Dental Journal, should carefully examine the relevant sections and submit their papers according to the writing rules.
In 2020, Cumhuriyet Dental Journal will welcome new prestigious Associate Editors and Editorial Board members. I would like to also welcome all colleagues who would like to join Cumhuriyet Dental Journal.

I owe many thanks to the people who contributed to the development of Cumhuriyet Dental Journal. First of all, I would like to thank the readers who followed the rich content of our journal. I would like to thank the Authors for their great effort and papers. I have special thanks to the Editorial Board members and Associate Editors. I owe a very special thanks to the Reviewers who have significantly helped the development of Cumhuriyet Dental Journal.

I wish a happy new year in 2020 and also happy readings in the last issue of 2019 !

Burak Buldur Co-Editor-in-Chief

How to Cite: Buldur B. Editorial: Cumhuriyet Dental Journal: Greetings from the Last Issue of 2019 and Special Thanks to All Members of CDJ! Cumhuriyet Dent J 2019:22:4:374. 